Article

\title{
A Partial Least-Squares Structural Equation Modeling Approach to Investigate the Audit Expectation Gap and Its Impact on Investor Confidence: Perspectives from a Developing Country
}

\author{
Fengju $\mathrm{Xu}{ }^{1}$ and Taslima Akther ${ }^{1,2, *(1)}$ \\ 1 School of Management, Wuhan University of Technology, Wuhan 430070, China; xufengju@whut.edu.cn \\ 2 Department of Accounting \& Information Systems, Jagannath University, Dhaka 1100, Bangladesh \\ * Correspondence: taslima@ais.jnu.ac.bd or limaais.du@yahoo.com
}

Received: 11 September 2019; Accepted: 15 October 2019; Published: 18 October 2019

\begin{abstract}
The aim of this study is to empirically explore the existence of the audit expectation gap and its impact on investors' confidence. As a maiden attempt to assess these relationships, we developed a model with higher order constructs using a partial least-squares structural equation model (PLS-SEM). Based on a questionnaire survey with auditors and institutional investors, as one of the main users of audited financial statements, this study explored investors' perceptions of both unreasonable and sensible audit expectation gaps from diverse aspects. The findings of this study revealed that the existence of an audit expectation gap was negatively related to investors' confidence, and the greater the audit expectation gap was, the lower the investors' confidence on audit. It was also found that auditors' perceived independence and improved level of communication were negatively related with the audit expectation gap but positively related with investors' confidence. Moreover, the monitoring role of independent audit oversight acts as a moderator among auditors' perceived independence, auditors' improved level of communication, audit expectation gap, and investors' confidence. As the innate characteristic of an audit is to resolve conflict between owners and management of the organization, this study provides insight about what the investors (owners) expect from the audit and how to mitigate those expectation gaps.
\end{abstract}

Keywords: audit expectation gap; investors' confidence; auditors' perceived independence; auditors' improved communication; independent audit oversight

\section{Introduction}

Audits perform an indispensable economic function in serving the public interest by reinforcing trust and confidence in financial reporting [1,2]. The demand for auditing arises from the conflict between the agent (management) and principal (owners), as stated in agency theory [3,4]. Consequently, with the collapse of giants such as Enron and WorldCom, innumerable vicissitudes have commenced in the guiding construction of statutory auditing since the enactment of the Sarbanes Oxley Act (SOX) in 2002, where the goal was to reinstate confidence through the auditing of financial statements $[5,6]$. Having trust and confidence in auditing financial statement is vital because this confidence greases the wheels of the capital markets [7]. For the sustainable capital market, it is obvious that investors have confidence in the audit of financial statements. Nevertheless, for decades, the auditing profession has been disquieted with high levels of litigations and accusations due to the failure of auditors to meet society's expectations, affirming an audit expectation gap (AEG), which, in turn, undermines confidence in the audit function [8-10]. "Clients have clear role expectations of professionals in people-based services such as accountants, lawyers, doctors and they will evaluate service encounters on the basis of 
the perceived role performance of the service provider and compliance with those expectations is the important base for evaluating the quality and the effectiveness of the service provided [11]". Barker [12] proclaims that society's resilience driven by proficient personnel is the "heartbeat of that profession"; hence, if such confidence is betrayed, professionalism is damaged and, subsequently, auditors become ineffective [13]. According to a research report from the Financial Reporting Council [14] investors' confidence in the audit is closely related to the level of the audit expectation gap, and confidence exists when auditors are believed to act independently of client companies.

On the eve of 2018, due to the collapse of Carillion Construction Company in the UK, the audit expectation gap was discerned from an up-to-the-minute angle [15]. The audit expectation gap is a serious concern in the audit profession and the greater the breach of expectations is, the lower the credibility, netting potency and esteem with the auditors' function [16]. Hence, to rejuvenate society's confidence in the audit functions and to extenuate the litigation and accusation against the auditors, the audit expectation gap should be significantly reduced, if not eliminated [17]. Auditor independence is the bosom of the audit expectation gap [18]. The more independent the auditor, the less the audit expectation gap and the higher the confidence in auditors' work $[16,19]$. The expectation gap is often referred to as the communication gap between the auditors and the clients, and users face difficulties in understanding the intended meaning of the audit report [20]. Standard setters and the auditing profession pay significant attention to closing any communication gaps with clients, since such a gap can erode confidence in an audit report and trigger unnecessary litigation [10,21,22]. Agency theory references the identified statutory persistence of audits as necessary to protect the stockholders [2-4]. The neo institutional theory emphasizes that organizations seek to gain legitimacy in the social context where they operate, and an audit expectation gap seriously impairs that legitimacy [23]; where regulation of external audit enhances that legitimacy and ensures public interest [6].

There exists a significant research gap concerning which audit expectation gap actually exists and what the consequences of such gap in contemporary time are, especially from a non-Anglo-American environment. To our knowledge, this is the first study to empirically investigate the impact of the audit expectation gap on investors' confidence. Along with the global rise in financial scandals, Bangladesh has also occupied space in the stock market crash of 2010-2011, and massive chaos in the banking sectors has led to the question about the role of auditors. USA responded to the aftershock of the corporate crisis through the enactment of SOX Act 2002 and established a public company accounting oversight board [24] whereas, Bangladesh parliament passed the financial reporting act (FRA) 2015 and urged to establish financial reporting council (FRC) under this act [25]. SOX contrived a new epoch for the audit profession by culminating a century of self-regulation and inaugurating independent audit oversight. Bangladesh has started its journey towards independent control of the audit profession by ordaining FRA and establishing FRC. As a consequence of this act, accounting practitioners and professionals flourished beneath the first-hand guiding requisite with the formation of the financial reporting council (FRC), which essentially caused the termination of an era of self-regulation [26]. However, considering manifold issues, this study introduces three important research questions, such as if an audit expectation gap actually exists, whether the audit expectation gap has any impact on investors' confidence, and how to mitigate those gaps to uphold the investors' confidence.

To address these research questions, a questionnaire survey was sent to auditors and institutional investors, as one of the main users of audited financial statements and included 174 respondents. Institutional investors include chief executive officers or managerial-level employees of different investment firms and merchant banks, and auditors include qualified chartered accountants. As a maiden attempt to portray the relationship, a higher-order model has been constituted and assessed with pragmatic exploration using the partial least-squares structural equation model (PLS-SEM). The research has made a noteworthy contribution to the audit literature from several perspectives. First, exploring the relationship between audit expectation gap and investors' confidence is the theoretical uniqueness of the study. Besides, stating the relationship between the audit expectation gap, auditors' perceived independence, and auditors' improved communication as well as portraying the monitoring 
role of independent audit oversight also provides a theoretical contribution in the audit literature. Second, reforms in audit regulations are usually made to fulfil the users' expectation, and if those reforms are not based on the proper judgment of what the users actually anticipate; those reforms will bear more cost than benefit. Our results provide guidance to the regulators, as each dimension of the audit expectation gap may inform the regulators which gap actually exists and how to mitigate those gaps to retain greater confidence in the audit. Third, use of a novel methodology, the partial least-squares structural equation model (PLS-SEM) and building type II formative reflective model, to portray the stated relations make the study worthwhile methodologically. Finally, as most of the audit research focuses on the Anglo-American setting, our study's geographic focus on a developing economy perspective will bring the audit regulators and practitioners new insight regarding the role of auditors in building investors' confidence.

The subsequent segments of this paper present as follows: A review of the related literature and hypothesis development in Section 2 followed by a description of data and methodology in Section 3. After that, Section 4 includes results; Section 5 discussions, implications, and study limitations; and Section 6 conclusions.

\section{Review of Related Literature and Hypothesis Development}

\subsection{Audit Expectation Gap (AEG)}

The audit expectation gap (AEG) exists when auditors and the public embrace dissimilar beliefs regarding the auditor's obligations and responsibilities and the messages channeled by the audit report [27-30]. AEG is the deviation of notion between auditors and the public about the duties and responsibilities assumed by auditors and the messages conveyed by audit reports $[1,27,31]$. Moreover, AEG subsists when auditors and the public embrace dissimilar beliefs regarding the auditor's obligations and responsibilities and the messages channeled by the audit report [29,32,33].

In this study, based on Porter's model [8], a more plausible delineation of AEG has been portrayed mainly from two paradigms: the unreasonable gap and the sensible gap (see Figure 1).

(a) Unreasonable gap: The gap between what the society believes in their mind what auditors can achieve and what practically they can achieve. It can also be referred to as failure of the public to understand the aim and scope of auditing and develop unreasonable expectations.

(b) Sensible gap:

(i) Sensible performance gap: What society can sensibly expect from the auditors about the actual level of performance of auditors and the standard of performance described by the current regulation. It can also be denoted as failure of the auditor to understand their own responsibilities under the current audit regulation regime.

(ii) Sensible standard gap: What society can sensibly expect from the auditors if there is an amendment in the current legislation based on equitable demand from the participants and if it is cost-effective in doing so. It can also be mentioned as failure of the standard setters if the current standards fail to communicate auditors' responsibilities clearly or reflect the users' logical demand for amendments to the standards.

As auditing is a powerful tool to bolster investor confidence with the results of business operations, many expectations are influenced by the role played by the external auditors [34]. There has been a noteworthy expectation gap amid what financial statements customers presume an audit is conveying and what the audit profession considers it is delivering. This gap becomes awkward for auditors during a corporate catastrophe, and special attention has focused on the role of the auditor [20]. Users have tremendous expectations regarding the auditor's role in fraud detection, and some researchers have revealed AEG in the areas of the auditor's responsibility for fraud detection [19,23,35-39] Although, according to [40], it is clear that the main concern for the deterrence and discovery of fraud rests with 
both the management and the governing body of the entity, and the auditor is accountable for attaining reasonable assurance that the financial statements, as a whole, are free from substantial malapropism, there still exists huge expectations regarding the matter.

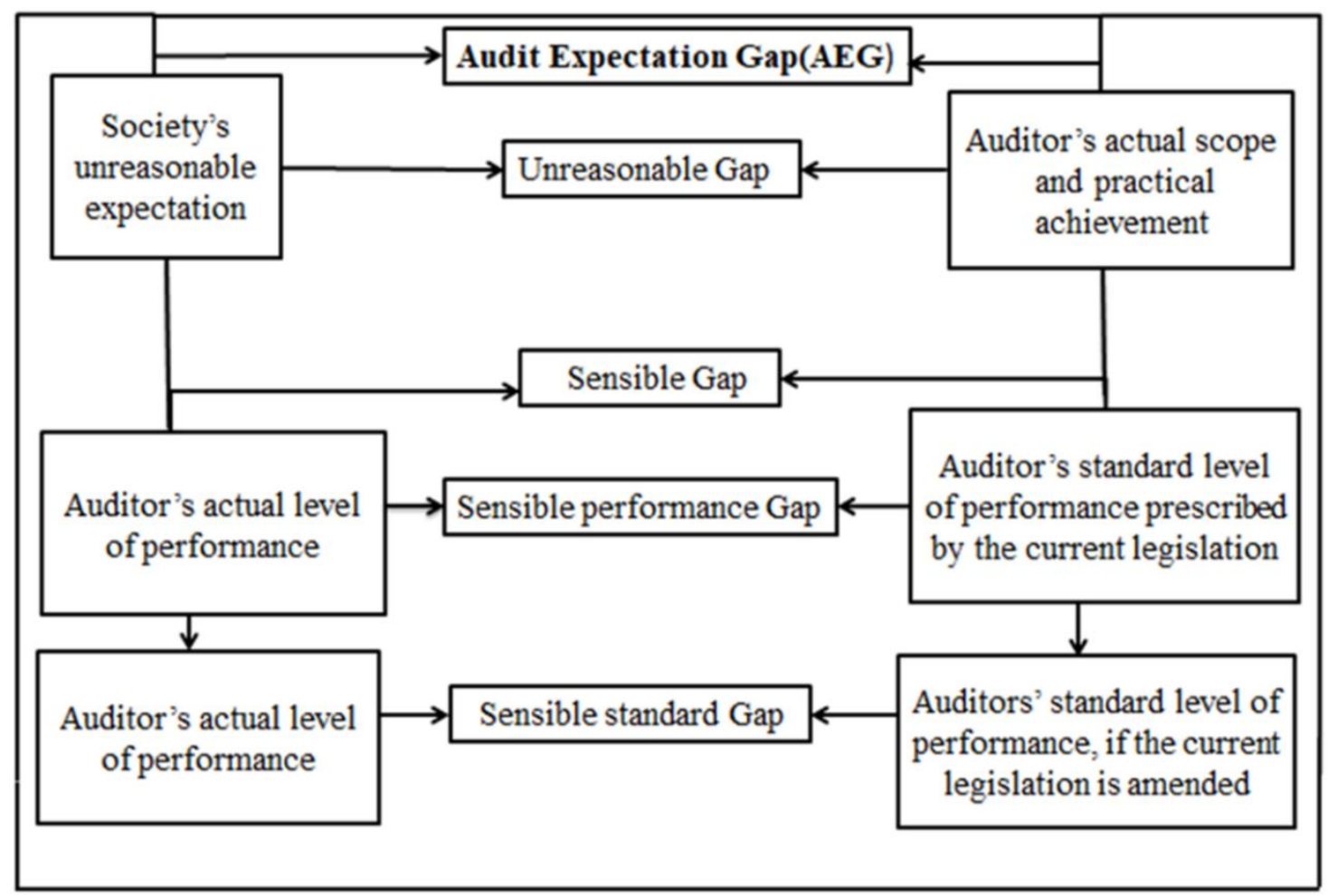

Figure 1. Audit Expectation Gap (AEG) in the contemporary regime. Source: Authors' own compilation based on Porter's model of audit expectation gap, 1993 [8].

Nevertheless, there is imprecise and pragmatic substantiation of significant communication gaps in the audit report, and there has been extensive exertion in shortening these gaps [20,41-43]. Moreover, significant AEG was also found in the dependability and usefulness of the audit report $[35,44]$. Users have difficulty in understanding the basic notions in the audit report such as reasonable assurance, materiality, and sampling [22]. Porter [41] mentioned that in the UK and New Zealand, $47 \%$ of financial statement users never or seldom read an entity's audit opinion.

After the 2007 banking disaster, the question was raised as to why numerous banks were in distress and that the world's financial organism was at risk, though there was barely any warning regarding the matter [45]. Management reports on their company's ability to continue as a going concern [46,47]; whereas auditors are required to issue a specific statement in the auditor's report on the appropriateness of management's use of the going concern assumption [48]. Audit reports need to contain material uncertainties related to the going concern, as well as first-hand requisites, to encompass the sufficiency of confessions for "close call' insight in the germane financial reporting framework, while the occasions or surroundings are acknowledged that may cause substantial qualms on an entity's capability to endure as a going concern $[49,50]$.

The management discussion and analysis segment of an annual report is vital in providing increased information to the markets after earnings, and also it is worthwhile in forecasting inevitable economic consequences [51]. However, current auditing standards do not entail the auditor to audit the information in the other parts of the annual report as a fragment of the financial statement audit [20]. Many companies are already underway in divulging information allied to the sustainability of their business [52]. Companies craving to augment their reliability and status are further likely to have their sustainability reports assured [53] and investors have an inclination to receive environmental and social 
responsibility information from a third-party source, therefore, exemplifying trepidations around the credibility of this sort of disclosure [54,55] Although the recent revised audit report requires the auditors to disclose information on the entity's other information [50], the opinion on the other information will add more credibility to this information. The existing literature on the audit expectation gap does not provide clear evidence of users' expectations regarding the assurance on other information beyond the entity's financial statements. We developed hypotheses on the basis that, along with the auditors' role on the audit of financial statements, an audit expectation gap may exist regarding the auditors' role of providing assurance on the information beyond the financial statements.

Therefore, considering the above-mentioned issues, we developed the following hypothesis:

Hypothesis 1a (H1a). The audit expectation gap (AEG) is linked with the auditors' responsibility for fraud detection (ARF), meaning and usefulness of the auditor's report (MUA), the expectation for going concern reporting assessment (EGCR), and also expectation for assurance on other information (EOA).

\subsection{Auditor's Perceived Independence (API)}

Auditor independence is considered a capstone of the audit profession because it has been assumed to be the foundation for public trust [56-59]. It has two distinct dimensions such as independence in fact, which is an unbiased mental attitude of the auditor, and independence in appearance, which is the perception by a reasonable observer that the auditor has no relationship with an audit client that would suggest a conflict of interest; however, independence in fact is unobservable [60]. Providing non-audit services create role conflicts and have deleterious repercussions on objectivity and capability to accomplish an unprejudiced audit [61-63]. Due to the worthwhile compensation for the non-audit services, auditors may act in a way uncomplimentary to the stakeholders to shield their self-absorption $[64,65]$.

Though a chain of moral principles has been espoused, decriers linger to contend that mixture of both audit and non-audit services are incompatible [33,66]. Salehi et al. [67] instituted that the grounds for plummeting independence are the financial dependency of the auditor on the clientele and the endowment of providing non-audit services. Due to the inheritance of providing mixed services, auditors perform diverse roles at the same time such as a consultant to the management and also as a liberated auditor to the shareholders; therefore, auditors are prospective in an incompatible locus [68].

Auditor tenure of five years or more does influence auditor independence [69]. Bangladesh implemented the role mandatory audit firm rotation after 3 years. A persistent association between auditor and clientele may induce the auditor to unsuspectingly acclimate to minor flaws in the clientele's financial accounting review that may disguise a flagging monetary stance [70]. Regulators and policymakers are reconsidering the issue of compulsory auditor alternation and making vigorous strides concerning the process [24]. The audit committee displays an arbitrating function serving to resolve the incongruities between the auditor and the client [71]. The auditor's independence is protected through effective communication with the active audit committee [72]. The trio of audit functions that involve external auditors, internal auditors, and audit committees is indispensable for conserving corporate accountability, and participants should have interconnections and work together in a mutually compassionate way; moreover, the audit committee should have the supremacy and concern to ask about any dearth [41]. Thus, we developed the following hypothesis:

Hypothesis $\mathbf{1 b} \mathbf{( H 1 b ) . ~ A u d i t o r ' s ~ p e r c e i v e d ~ i n d e p e n d e n c e ~ ( A P I ) ~ i s ~ l i n k e d ~ w i t h ~ r e s t r i c t i o n ~ i n ~ p r o v i d i n g ~ n o n - a u d i t ~}$ services (RNAS), the mandatory auditors rotation (MAR), and effective communication with the active audit committee (AAC).

As a cornerstone of bridging the audit expectation gap, maintaining the auditors' perceived independence is important because without perceived independence, an audit report would be regarded as nothing more than a company's publicity effort [33]. Bazerman et al. [58] concluded that 
"audit failures are the natural product of the audit-client relationship", and restricting the auditors in providing non-audit work and increasing independent audit oversight are vital to mitigate audit-related expectations. Hence, we posited the following hypothesis:

Hypothesis 1c (H1c). Auditor's perceived independence (API) has a negative impact on the audit expectation $\operatorname{gap}(A E G)$.

\subsection{Auditor's Improved Level of Communication (AILC)}

Expectation gaps may arise due to the lack of proper communication with the client. Standard setters and the auditing profession have important and obvious interests in reducing the communication gap since a gap can erode confidence in an audit report, lead to poor decisions, and trigger unnecessary litigation $[10,20,21,43,73-75]$.

The existing audit report is merely a "boiler plate", and it is not ample enough for the discernment of the stakeholders regarding the company's exact affairs [20]. The International Auditing \& Assurance Standard Board dispensed ISA 700 and the revised version of ISA 700 in a mandate to advance the users' apprehension of an audit and the steadfastness of audited financial statements, and ISA 701 incorporated key audit matters in the audit report $[76,77]$. Collaborating on the key audit matters, explaining the going concern issues explicitly in the audit report, revealing the title of the engagement partner in the audit report, and requiring the presentation of the opinion section of the audit report in the beginning are some of the changes that have been implemented to expand the audit report [50].

Education can be an imperative function in reducing audit-related expectation [38]. Epstein et al. [78] ascertained that more sophisticated stakeholders are less likely to mandate upper auditor assurance, and the anticipation gap could be tapered by amplifying civic cognizance regarding the traits and restrictions of an audit. Sophisticated accounting information users can more thoroughly understand the accounting choices and the qualities of accounting information; hence, they can take the more useful decision [79]. Monroe et al. [31] recommended that education might be an effective tactic to taper the audit expectation and communication gap. Therefore, we instituted the following hypothesis:

Hypothesis 1d (H1d). The auditor's improved level of communication (AILC) is linked with improving the audit report (IAR) and ensuring audit education (EAED).

Some prior studies suggested that communication gaps exist between auditors and users of financial statements $[32,35,80]$. Regulators of the audit profession have tried to ensure that there is a slight or no gap between what the auditor intends to communicate and what is perceived by the users as communication gap, which would corrode confidence in the audit report and trigger needless lawsuits against the profession; hence, better communication from the part of auditors will reduce the audit expectation gap [42]. Moreover, [81], found that the long-form audit report reduces the expectation gap over time. Therefore, we posited the following hypothesis:

Hypothesis 1e (H1e). The auditor's improved level of communication (AILC) has a negative impact on the audit expectation gap (AEG).

\subsection{Investors' Confidence (ICF)}

Agency theory states that the identified statutory persistence of an audit is to shield stockholder interest as one of the main users of audited financial statements [2,4]. Having trust and confidence in audits of financial statements is vital because this confidence greases the wheels of the capital markets [7]. Contemporary corporate scandals and allied audit disasters recommend that there is a severe detachment between what the users anticipate of the auditors and what the auditors presume of themselves, and these fiascos are termed as the trust gap between the auditors and the users of the audited financial statements [82]. Investors' confidence on statutory audits has substantially 
declined due to incompatible fraud disclosures and refutable accounting practices [83]. Being a socially challenged metempsychosis, the greater the expectation gap is, the lower the credibility, earning prospects and the reputation connected with the auditors' work [16]. The buyer of the audit service can expect that the audit service will maintain the highest level of quality to retain confidence [84]. Hence, the audit expectation gap may pose a negative impact on investors' confidence. Hence, we posited the following hypothesis:

Hypothesis 2 (H2). There exists a negative relationship between the audit expectation gap (AEG) and the investors' confidence (ICF).

According to a research report from the financial reporting council in the UK, [14], confidence exists when auditors operate independently of "client" companies. For an audit to be credible and reliable, it must be performed by someone who is independent and cannot be influenced by position and power [85]. The greater the audit independence is, the higher credibility of the audited financial statements [86].

Hypothesis 3a (H3a). The auditor's perceived independence (API) has a positive impact on the investors' confidence (ICF).

The broader investor groups and the media fail to understand the purpose and remit of audit; therefore, they advocate for better communication by the profession to improve the public's understanding of audits. There exists a communication gap among the users regarding the nature of the audit's function and also the meaning of the audit report and a forum is needed for the interface among auditors, management, and users of financial statements to boost confidence in the audit [87]. There exists a communication gap among the auditors and users of the financial statements in understanding the message conveyed by the standard audit report, although it provides users heightened confidence about the usefulness of audit reports; hence, an improved audit reporting model is necessary [42].

Therefore, we proposed the following hypothesis:

Hypothesis $\mathbf{3 b} \mathbf{( H 3 b )}$. The auditor's improved level of communication (AILC) has a positive impact on the investors' confidence (ICF).

\subsection{The Role of Independent Audit Oversight}

The neo-institutional theory states that organizations are socially constructed and attempt to gain legitimacy in the social context in which they operate [88]. The regulation of statutory auditing is motivated by legitimacy-seeking behaviors and is important to provide reliable information to the society, ensure proper function of capital markets, and also concern public interest [6]. After huge chaos in the financial market, the US government passed the SOX act 2002 and established the Public company accounting oversight board (PCAOB) to terminate the self-regulation. Unlike the US, many countries like UK, Australia, Holland, Canada, Japan, and Malaysia also established independent bodies to regulate the auditors. Consequently, with a motive to ensure public interest, Bangladesh also established FRC. To enhance the statutory audit regulation, Bangladesh parliament also passed the financial reporting act (FRA) of 2015, and the Financial Reporting Council (FRC) is an important apparatus of the FRA [89].

The responsibilities of FRC include inaugurating financial reporting requisites for all business entities in the country; comprising the obligation to espouse accounting and auditing touchstones; providing a authorization to the auditors; accrediting the auditors and endorsing the audit firms; observing and appraising the financial reporting of publicly listed companies; and applying any punishment for rule violations, as well as imposing acquiescence with the accounting and auditing criteria and the relevant ethical requisites [25]. FRC can play a big role as an independent regulator of 
the audit profession. As the president of FRC rightly said, "Self-regulations are no longer there, people are getting affected; so, regulation is needed for the sake of people and the society [90]".

Therefore, we developed the following hypotheses:

Hypothesis 4a (H4a). The active role of the independent audit oversight moderates the effect of auditors' perceived independence (API) on audit expectation gap (AEG).

Hypothesis $\mathbf{4 b} \mathbf{( H 4 b )}$. The active role of the independent audit oversight moderates the effect of the auditors' improved level of communication (AILC) on the audit expectation gap (AEG).

Hypothesis 4c $(\mathbf{H 4 c})$. The active role independent audit oversight moderates the effect of auditors' perceived independence (API) on investors' confidence (ICF).

Hypothesis $4 \mathbf{d}(\mathbf{H} 4 \mathbf{d})$. The active role of the independent audit oversight moderates the effect of the auditors' improved level of communication (AILC) on the investors' confidence (ICF).

The study's conceptual model is depicted in Figure 2. The order of the construct and the direct and indirect effects are illustrated as well.

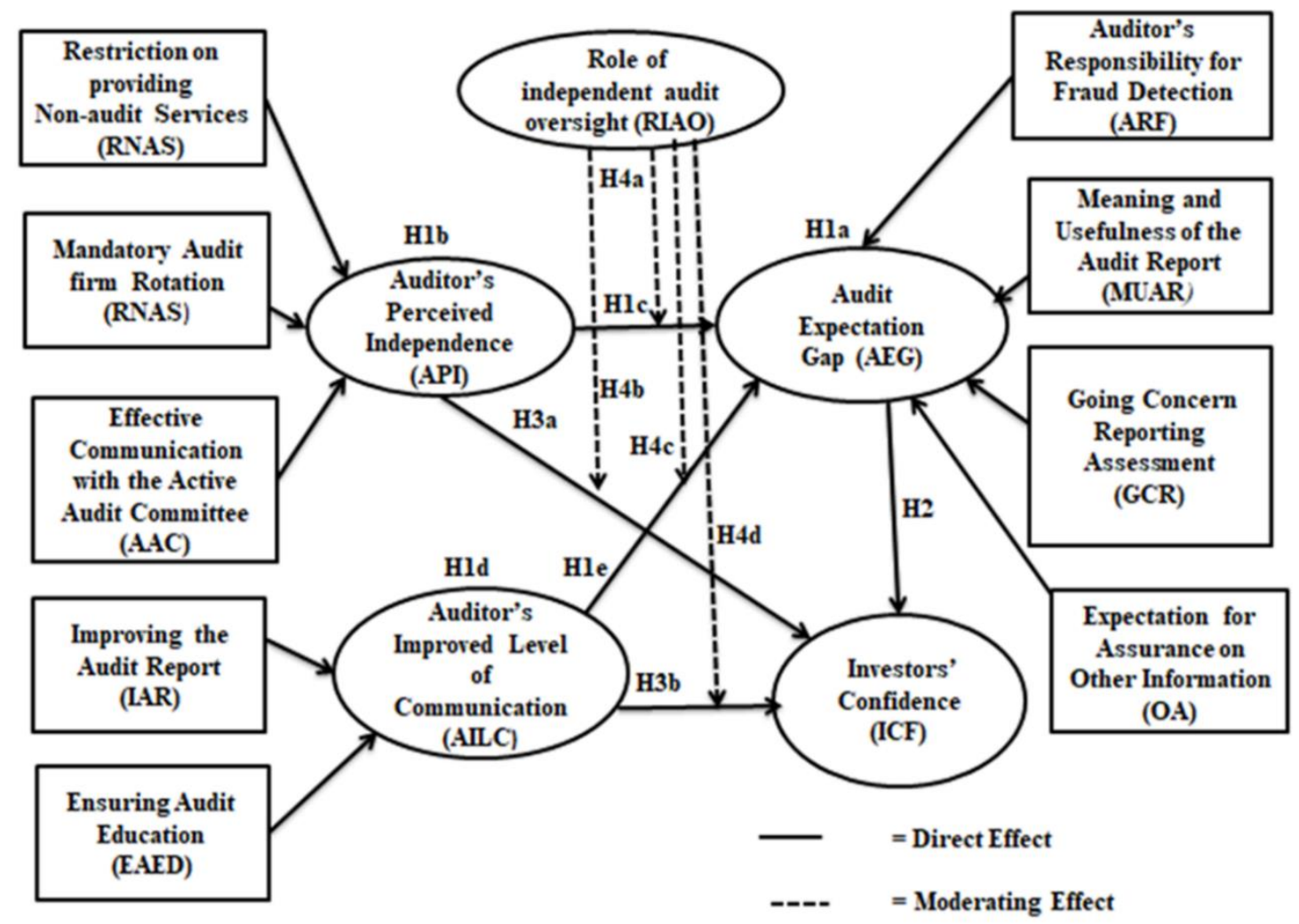

Figure 2. Conceptual Model.

\section{Research Method}

\subsection{Data}

A questionnaire was used as a research instrument, as the researchers of the AEG regime mostly used questionnaires $[23,28,91]$. In the beginning, the concept of the research and the construct and item development process were discussed with the subject experts, university professors, $\mathrm{PhD}$ researchers, and chartered accountants. A wide range of academic and professional literature and the contemporary audit standards was reviewed to develop the research instrument. The intended questionnaire was 
pre-tested by 10 respondents, as pre-testing the questionnaire with 5 to 10 respondents is apposite [92]. From the feedback in the pre-testing, some questions were modified, and some were obliterated considering the importance of each question in our research model. The questionnaire was designed on the basis of a 5 -point Likert scale anchored as: $5=$ strongly agree; $4=$ agree; $3=$ no opinion; $2=$ disagree; $1=$ strongly disagree. A list of construct and items has been included in Supplementary Material.

Mainly auditors and institutional investors, as one of the main users of audited financial statements, were considered as respondents. We chose the institutional investors as the prime users of audit reports. Institutional investors are specialized financial institutions including banks, brokerage houses, mutual funds, portfolio management companies, etc. [93]. Individual investors often do not have the ample proficiency and prospect to follow the market constantly, whereas institutional investors have been molded in capital markets as collective investment institutions [94]. A random sampling technique was used in the study. Auditors included qualified chartered accountants selected randomly from the name list available on the website of Institute of Chartered Accountants of Bangladesh (ICAB). The qualification of auditors was that they passed the final level of the chartered accountancy examination. Investors were selected randomly from different investment firms and merchant banks that were institutional investors and also own beneficiary owner (BO) account in Dhaka stock exchange (DSE) of Bangladesh. Data were collected from the chief executive officer or the managerial-level employees of the institution who worked as institutional investors. The survey took place between February 2019 to April 2019. A face-to-face interview was conducted during the survey, and respondents were ensured about their anonymities and confidentiality of the information provided. They were also assured that they might withdraw their assent to participate in the survey at any time without reverberation. No gifts or incentives were offered to the respondents to avoid potential biases, and all were voluntary participants. The respondent groups possessed enough accounting and audit qualifications and experiences, and most of them were highly educated (see Table 1).

Table 1. Sample Characteristics.

\begin{tabular}{ccc}
\hline Variable/Dimension & Frequency & Percentage \\
\hline Respondents Groups & 76 & 44 \\
Auditors & 98 & 56 \\
Investors & & \\
Gender & 141 & 81 \\
Male & 33 & 19 \\
Female & & 29 \\
Level of Education & 50 & 23 \\
Graduate & 40 & 47 \\
Post Graduate & 81 & 1 \\
Professional Degree e.g., ACA/ACMA/FCA/FCMA & 3 & 20 \\
PhD/others & & 41 \\
\hline Accounting \& Audit related Experiences & 35 & 27 \\
1 to 3 years & 72 & 12 \\
4 to 6 years & 46 & \\
7 to 9 years & 21 & \\
$10+$ years & & \\
\hline
\end{tabular}

Two hundred fifty (250) respondents were approached, and 186 responses were received with a $74 \%$ response rate. After removing incomplete responses, the final sample was 174 usable questionnaires for the analysis. Early respondents (112 cases) and late respondents ( 62 cases) were divided into two different data sets. A T-test was done to see the mean differences between these two groups, and no significant differences were found; hence, we concluded the dataset was free from non-response bias. A reliability test of the data was done in SPSS 24 (Version 24.0.) [95]; the value of Cronbach's alpha was 0.85 , thereby falling in the acceptable range from 0.70 to 0.95 [96]. The Jarque-Bera test [97] was done 
to assess the normality of the data set. The result was significant at $p<0.05$, and it shows that the data set was not normal, and nonparametric statistical tools, such as bootstrapping, are justified here [98].

\subsection{Methodology}

Data were analyzed using the structural equation model (SEM) in Smart-PLS version 3.2.7 software [99]. If the model is complex with many constructs and items, includes a formative construct, does not fulfil the normality assumption of the data set, deals with a comparatively small sample size, and the predicting key construct is the research goal, then using PLS-SEM is more appropriate $[98,100]$. In this study, the focus was placed on second-order hierarchical latent variable models that included formative relationships. According to [101], developing a model with a higher-order formative construct is referred to as a type II reflective-formative model. In the case of erecting a type II model, the lower-order constructs are reflectively measured constructs that do not share a common cause but rather form a general concept that fully mediates the influence on the following endogenous variables. A PLS-based three-stage approach consistently estimates and tests hierarchical constructs specified as composites of common factors, which require three rounds of estimation [102]. The PLS-based three-stage approach was followed in this study to assess this higher-order model.

Formative indicators are assumed to be error-free [103]. Consequently, the concepts of internal consistency, reliability, and convergent validity are not meaningful when formative indicators are involved. Instead, theoretical rationale and expert opinion play a more important role in the evaluation of formative indices. Nevertheless, PLS-SEM also offers some statistical criteria for assessing the quality of the formative measurement model. According to [98], examining each indicator's weight (relative importance) and loading (absolute importance) and applying bootstrapping to assess their significance is important in assessing the formative model. The minimum number of the bootstrap sample is 5000. The examination of measurement properties for a formative construct could be performed by a multicollinearity test, the test of indicator validity (path coefficients significance), and optionally, if appropriate, a test-retest [104].

\section{Results}

\subsection{Assessing the Measurement Model}

A PLS algorithm was run, rather than a consistent PLS algorithm, in the Smart PLS version 3.2.7 software (Version 3) [99]. A consistent PLS algorithm assumes multicollinearity among the constructs and executes an adjustment of the reflective constructs' correlations to sort outcomes consistent with a factor model [105-107]. As it is a formative model, the concept of multicollinearity was absent here. Most of the loadings were significant at $\geq 0.70$ or $\geq 0.50$ [98] to form both the first-order construct and the second-order construct. However, any indicator carrying a loading of less than 0.50 was also retained according to their contribution to forming the construct and assuming there was no impact on the reliability of the constructs. To ensure that there was no multicollinearity, each indicator's variance inflation factor (VIF) value should be less than 5 [98,108]; less than 3.3 showed an excellent value [109] and less than 10 showed that no collinearity was commonly accepted [110].

Bootstrapping was done (174 cases, sample 5000). T-statistics of the corresponding weights were found to be significant with a bootstrapping sample at 5000. Weights of the construct were significant and positively contributed to forming the higher-order construct, and all indicators were retained, since the rule was supported; although, if an indicator's weight was not significant, the corresponding item loading was relatively high (i.e., $\geq 0.50$ ), or, if it was statistically significant, the indicator should usually be kept. Most of the VIF values were less than 3.3, materializing an excellent measure to form a formative higher-order construct. Table 2 presents an assessment of the measurement model. 
Table 2. Assessment of Measurement Model.

\begin{tabular}{|c|c|c|c|c|c|c|c|c|c|}
\hline Path & Indicator Loading & Indicator Weight & T-Stat & VIF & Path & Indicator Loading & Indicator Weight & T-Stat & VIF \\
\hline ARF1-ARF & 0.696 & 0.292 & 10.336 & 1.353 & ARF1-AEG & 0.467 & 0.016 & 2.411 & 1.647 \\
\hline ARF2-ARF & 0.914 & 0.312 & 17.922 & 1.537 & ARF2-AEG & 0.470 & 0.006 & 1.988 & 1.575 \\
\hline ARF3-ARF & 0.897 & 0.307 & 17.558 & 4.528 & ARF3-AEG & 0.346 & 0.026 & 2.070 & 4.558 \\
\hline ARF4-ARF & 0.770 & 0.307 & 9.628 & 5.134 & ARF4-AEG & 0.347 & 0.027 & 2.768 & 5.444 \\
\hline MUAR1-MUAR & 0.790 & 0.216 & 16.305 & 2.008 & MUAR1-AEG & 0.556 & 0.004 & 2.081 & 2.271 \\
\hline MUAR2-MUAR & 0.871 & 0.240 & 17.833 & 2.657 & MUAR2-AEG & 0.611 & 0.019 & 2.351 & 2.923 \\
\hline MUAR3-MUAR & 0.794 & 0.237 & 16.795 & 2.024 & MUAR3-AEG & 0.591 & 0.054 & 1.980 & 2.392 \\
\hline MUAR4-MUAR & 0.885 & 0.244 & 20.842 & 2.999 & MUAR4-AEG & 0.623 & 0.114 & 2.068 & 3.325 \\
\hline MUAR5-MUAR & 0.879 & 0.247 & 20.171 & 2.885 & MUAR5-AEG & 0.620 & 0.018 & 2.304 & 3.350 \\
\hline GCRA1-GCR & 0.531 & 0.243 & 5.207 & 1.151 & GCRA1-AEG & 0.344 & 0.049 & 2.874 & 1.260 \\
\hline GCRA2-GCR & 0.563 & 0.275 & 4.562 & 1.955 & GCRA2-AEG & 0.420 & 0.120 & 1.924 & 1.206 \\
\hline GCRA3-GCR & 0.808 & 0.440 & 7.735 & 1.419 & GCRA3-AEG & 0.621 & 0.063 & 1.771 & 1.124 \\
\hline GCRA4-GCR & 0.724 & 0.296 & 7.503 & 1.801 & GCRA4-AEG & 0.415 & 0.004 & 1.773 & 1.279 \\
\hline EOA1-OA & 0.596 & 0.305 & 15.271 & 1.421 & OA1-AEG & 0.409 & 0.127 & 1.845 & 2.053 \\
\hline EOA2-OA & 0.833 & 0.485 & 15.295 & 1.426 & OA2-AEG & 0.706 & 0.235 & 1.718 & 2.078 \\
\hline EOA3-OA & 0.843 & 0.491 & 2.318 & 1.012 & OA3-AEG & 0.710 & 0.147 & 1.749 & 1.132 \\
\hline RNAS1-RNAS & 0.673 & 0.262 & 8.802 & 1.195 & RNAS1-API & 0.487 & 0.085 & 2.152 & 1.292 \\
\hline RNAS2-RNAS & 0.770 & 0.276 & 13.363 & 1.400 & RNAS2-API & 0.501 & 0.053 & 1.736 & 1.485 \\
\hline RNAS3-RNAS & 0.039 & 0.023 & 13.273 & 1.421 & NAS3-AEG & 0.020 & 0.035 & 1.849 & 1.960 \\
\hline RNAS4-RNAS & 0.839 & 0.383 & 18.242 & 1.900 & RNAS3-API & 0.694 & 0.151 & 2.892 & 2.156 \\
\hline MAR 1-MAR & 0.694 & 0.344 & 8.183 & 1.250 & MAR 1-API & 0.442 & 0.042 & 3.938 & 1.333 \\
\hline MAR 2-MAR & 0.839 & 0.411 & 15.504 & 1.565 & MAR 2-API & 0.522 & 0.043 & 3.767 & 2.663 \\
\hline MAR 3-MAR & 0.832 & 0.500 & 14.455 & 1.450 & MAR 3-API & 0.639 & 0.189 & 3.299 & 1.736 \\
\hline AAC1-AAC & 0.799 & 0.493 & 13.733 & 1.325 & AAC1-API & 0.601 & 0.182 & 3.315 & 1.447 \\
\hline AAC2-AAC & 0.811 & 0.464 & 13.516 & 1.350 & AAC2-API & 0.564 & 0.083 & 3.456 & 1.510 \\
\hline AAC3-AAC & 0.633 & 0.363 & 7.551 & 1.114 & AAC3-API & 0.442 & 0.065 & 1.730 & 1.053 \\
\hline IAR1-EAR & 0.725 & 0.214 & 9.301 & 1.961 & EAR1-AILC & 0.488 & 0.062 & 1.772 & 2.041 \\
\hline IAR2-EAR & 0.925 & 0.226 & 10.946 & 2.736 & EAR2-AILC & 0.501 & 0.099 & 1.769 & 2.872 \\
\hline IAR3-EAR & 0.802 & 0.215 & 8.840 & 2.969 & EAR3-AILC & 0.476 & 0.120 & 1.713 & 3.042 \\
\hline EAED1-EAED & 0.843 & 0.510 & 10.410 & 1.306 & EAED1-AILC & 0.587 & 0.230 & 3.450 & 1.495 \\
\hline EAED2-EAED & 0.790 & 0.426 & 12.789 & 1.383 & EAED2-AILC & 0.485 & 0.141 & 2.648 & 1.450 \\
\hline EAED3-EAED & 0.665 & 0.349 & 8.295 & 1.235 & EAED3-AILC & 0.401 & 0.112 & 2.292 & 1.322 \\
\hline ICF1-ICF & 0.658 & 0.288 & 7.098 & 1.428 & - & - & - & - & - \\
\hline ICF2-ICF & 0.825 & 0.383 & 10.812 & 1.701 & - & - & - & - & - \\
\hline ICF3-ICF & 0.823 & 0.344 & 10.833 & 2.733 & - & - & - & - & - \\
\hline ICF4-ICF & 0.789 & 0.268 & 8.659 & 2.623 & - & - & - & - & - \\
\hline
\end{tabular}

Notes: Bold values are the significant VIF values. 


\subsection{Assessing the Structural Model}

For assessing the structural model, bootstrapping was done with 174 cases and a sample of 5000. The statistical assessment from bootstrapping has been displayed in Table 3. The result of H1a indicated that the audit expectation gap, AEG, was a second-order formative construct designed by three first-order latent constructs including auditors' responsibility for fraud detection, ARF, going concern reporting assessment, GCR, and expectation for assurance on other information, EOA. No expectation gap was found regarding the meaning and usefulness of auditors' report, as MUAR did not significantly formulate as a construct of AEG. The result of H1b, substantiated that auditors' perceived independence, API, is a second-order formative construct influenced by three first-order latent constructs including restriction on provision of non-audit services, RNAS, mandatory auditors' rotation, MAR, and also effective communication with the audit committee, AAC. Consequently, the result of H1d indicated that auditors' improved level of communication, AILC, is a second-order formative construct including two first-order latent constructs: improving the audit report, IAR, and ensuring audit education, EAED, respectively.

Table 3. Formation of Second-Order Constructs AEG, API, and AILC.

\begin{tabular}{ccccc}
\hline Second-Order Construct & First-Order Construct & Std. Beta & T-Statistic & $p$-Value \\
\hline AEG (H1a) & ARF & 0.018 & 11.187 & $0.000^{* * *}$ \\
& MUAR & 0.026 & 1.453 & 0.186 \\
& GCR & 0.025 & 6.736 & $0.000^{* * *}$ \\
& EOA & 0.020 & 8.537 & $0.000^{* * *}$ \\
\hline API (H1b) & RNAS & 0.031 & 16.680 & $0.000^{* * *}$ \\
& MAR & 0.029 & 13.445 & $0.000^{* * *}$ \\
& AAC & 0.028 & 11.352 & $0.000^{* * *}$ \\
\hline AILC (H1d) & IAR & 0.042 & 18.555 & $0.000^{* * *}$ \\
& EAED & 0.055 & 5.624 & $0.000^{* * *}$ \\
\hline
\end{tabular}

Notes: $p$ is significant at ${ }^{* * *}(p<0.01)$.

\subsection{Hypothesis Testing of Direct Relationships}

The result of hypothesis testing of direct relationships has been displayed in Table 4 . The results of H1c and H1e indicated that both auditors' perceived independence, API, and auditors' improved level of communication, AILC, negatively impacted the audit expectation gap (AEG). The result of $\mathrm{H} 2$ indicated that the audit expectation gap, AEG, negatively impacted the investor's confidence (ICF). The results of $\mathrm{H} 3 \mathrm{a}$ and $\mathrm{H} 3 \mathrm{~b}$ clearly stated that the auditors' perceived independence (API) and the auditor's improved level of communication (AILC) both positively impacted the investors' confidence (ICF).

Table 4. Hypothesis Testing of Direct Relationships.

\begin{tabular}{cccccc}
\hline Hypothesis & Path & Std. Beta & T-Statistic & $p$-Value & Decision \\
\hline H1c & API -> AEG & -0.013 & 3.260 & $0.000^{* * *}$ & Supported \\
H1e & AILC -> AEG & -0.050 & 2.892 & $0.000^{* * *}$ & Supported \\
H2 & AEG - ICF & -0.123 & 3.794 & $0.035^{* *}$ & Supported \\
H3a & API -> ICF & 0.100 & 2.866 & $0.030^{* *}$ & Supported \\
H3b & AILC -> ICF & 0.060 & 2.868 & $0.020^{* *}$ & Supported \\
\hline \multicolumn{6}{c}{ Notes: $p$ is significant at ${ }^{* * *}(p<0.01),{ }^{* *}(p<0.05)}$.
\end{tabular}

\subsection{Hypothesis Testing of Moderating Relationships}

The PLS algorithm was run, and bootstrapping was done again (174 cases, 5000 samples) by creating the moderating effect of RIAO, role of independent audit oversight, on the relationship among RIAO*API -> AEG; ROIA*AILC -> AEG; ROIA*API -> SC; ROIA*AILC -> SC. The results of H4a, H4b, $\mathrm{H} 4 \mathrm{c}$, and $\mathrm{H} 4 \mathrm{~d}$ stated that the moderating effect of the role of independent audit oversight (RIAO) on 
the relationship among API, AEG, and ICF was significant, whereas among the AILC, AEG, and ICF, it was not significant at $p<0.1$ (see Table 5).

Table 5. Hypothesis Testing of Moderating Relationships.

\begin{tabular}{cccccc}
\hline Hypothesis & Path & Std. Beta & T-Statistic & $p$-Value & Decision \\
\hline H4a & FRC ${ }^{*}$ API -> AEG & -0.017 & 2.571 & $0.010^{* *}$ & Supported \\
H4b & FRC $^{*}$ AILC -> AEG & -0.104 & 0.940 & 0.348 & Unsupported \\
H4c & FRC $^{*}$ API -> ICF & 0.049 & 2.280 & $0.038^{* *}$ & Supported \\
H4d & FRC $^{*}$ AILC -> ICF & 0.108 & 0.885 & 0.371 & Unsupported \\
\hline
\end{tabular}

Notes: $p$ is significant at ${ }^{* *}(p<0.05)$.

\section{Discussion, Implication, Study Limitation \& Future Research Direction}

\subsection{Discussion}

The aim of the study was to investigate the existence of an audit expectation gap (AEG) and also to assess the impact of that gap on the investors' confidence. The study's first research question was to assess which audit expectation gap actually exists. The study assessed the presence of some unreasonable audit expectation gap and also some sensible gap. In H1a, the result showed that a significant audit expectation gap existed regarding the auditor's responsibility for fraud detection, auditors' responsibility for going concern reporting assessment, and also expectation for the assurance on other information. Significant AEG was not found regarding the meaning and usefulness of the auditor's report. This indicated that users had a reasonable understanding regarding the meaning of the audit report and thought that the audit report was useful for decision making. This finding is consistent with some prior studies where researchers found AEG regarding auditor responsibility for fraud detection in different countries, e.g., Egypt [35-37,39,44]. We considered the gap regarding auditor responsibilities for fraud detection as an unreasonable gap because, according to international standards on auditing, ISA 240, auditors can provide reasonable assurance about the fairness of financial statements, and an auditor's opinion is not a guarantee of the accuracy of the financial statements [40]. However, as users expect auditors to be responsible for fraud detection, auditors may apply more professional judgment about detecting and preventing fraud. In H1a, this study also delineated that users possessed expectations regarding auditors' roles for the entity's continuity as a going concern. The investors considered the audit report as a guarantee of going concern and the sustainability of the entity; they also expected an early warning of the company's failure, if any. This finding confronts the study of [23] in Germany, as their study results pointed out that users possessed independent financial statement audits as a tool for prevention of fraud and considered them as an early warning system for the company's failure. This gap can be referred to as a sensible performance gap. The IAASB has recently announced the revised version of ISA 700 audit report, where a separate statement is included on the auditors' responsibility regarding the entity's ability to continue as going concern. Although the going concern assumption is one of the fundamental principles of preparing general purpose financial statements, auditors can provide better judgment and more specific information to the users regarding it.

Moreover, new insights of AEG have been identified in our study, such as expectation for assurance on other information. The users think that the other parts of the annual report, except financial statements, such as management discussion and analysis and corporate social and environmental reports are audited, although they are not. This gap can be referred to as a sensible standard gap. The current audit standards relating to other information states that the auditor's opinion does not cover the other information beyond the financial statements, and the auditor has no specific responsibility for determining whether or not other information is properly stated; however, the auditor reads the other information and reports if material inconsistency exists because the credibility of the audited financial statements may be undermined by material inconsistencies between the audited financial statements 
and other information [77]. The standard setters and professionals, thus, have an opportunity to redesign the scope and procedures for the assurance to be provided on the other information.

The second research question was whether the audit expectation gaps had any impact on the investors' confidence. Based on the empirical results in $\mathrm{H} 2$, this study inferred that the audit expectation gap negatively affected the investors' confidence. The larger the audit expectation gap is, the less the investors' confidence on audit will be. The third research question was how to mitigate audit expectation gap to uphold the investors' confidence. The results of H3a and H3b revealed that the most vigorous ways to mitigate users' audit expectation gap is to have the auditors maintain their perceived independence and to improve the level of communication with the users. Earlier, auditors' independence was found in H1B, with restrictions in providing non-audit services (RNAS), the mandatory auditors rotation (MAR), and effective communication with the active audit committee (AAC). Auditors can improve the level of communication by improving the audit report (IAR) and ensuring audit education (EAED) in H1d. This study finds that auditors' maintenance of perceived independence and improving the level of communication mitigates the audit expectation gap as well as induces the investors' confidence simultaneously.

Moreover, the study portrayed the role of independent audit oversight in the stated relationship between the audit expectation gap, auditors' perceived independence, auditors' improved level of communication, and the investors' confidence. The active role of independent audit oversight moderates the effect of auditors' perceived independence (API) on the audit expectation gap (AEG) and investors' confidence. The results of $\mathrm{H} 4 \mathrm{a}$ and $\mathrm{H} 4 \mathrm{c}$ indicated that the role of independent audit oversight significantly moderated the relationship between audit expectation gaps (AEG) and investors' confidence (ICF) as well as auditors' perceived independence (API) and investors' confidence (ICF). Although the results of $\mathrm{H} 4 \mathrm{~b}$ and $\mathrm{H} 4 \mathrm{~d}$ showed that the active role of independent audit oversight also moderated the effect of the auditors' improved level of communication (AILC) on the audit expectation gap (AEG) and the investors' confidence (ICF), the result was not statistically significant. Users' perceived that independent audit oversight can work more promptly to impose roles that will help induce auditors' perceived independence to reduce the audit expectation gap and also induce the investors' confidence. This study demarcates that the active role of independent audit oversight is dynamic in formulating policies for maintaining the auditors' perceived independence that will act in reducing the audit expectation gap and induce the investors' confidence.

\subsection{Implications of the Study}

This research is very pertinent, as the regulators of the audit profession assess investors' perception towards the audit, request annotations from them, and take actions according to their desires to improve the value of the audit $[24,48,75,81,111-113]$. However, this study has theoretical, practical, and also methodological contributions. First, exploring the relationship between audit expectation gap and investors' confidence is the theoretical uniqueness of the study. This study empirically infers that the existence of any audit expectation gap negatively affects the investors' confidence. The larger the audit expectation gap is, the less the investors' confidence on audit will be. Second, the literature on the audit expectation gap provides a basis and mixed evidence regarding the expectation gap on auditors' role for fraud detection, meaning and usefulness of the audit report, and also the responsibility of auditors to perform going concern assessments to some extent. This study delineates that no expectation gap exists between auditors and investors regarding the meaning and usefulness of audit reports. Investors largely expect auditors to perform fraud detection and going concern assessments. Moreover, this study discovers another new insight in the audit expectation gap, which is the auditors' role in assurance on other information. Other information means the information contained in the entity's annual report such as management discussion \& analysis, report on CSR, environmental report, etc., other than the financial statements. This other information is not audited by the auditors, although these are significant sources of information for investment decision making. This finding is unique in this study and has been referred to as a sensible standard gap. The current audit standard does not 
provide complete guidance regarding the auditors' role for assurance on other information. Although, the ISA 700 revised audit report includes a separate section in the auditor's report to identify the other information, explaining the management and auditors' responsibilities regarding other information. It is clearly mentioned that the auditor's opinion on the financial statements does not cover the other information and that the auditor does not infer any sort of assurance thereon $[50,77]$. As there exists an expectation gap between auditors and investors regarding the auditors' role in providing assurance on the other information, the current audit standards could be amended regarding the auditors' role in this area. In addition, exploring the two implements such as auditors' perceived independence and improved communication, which reduces the audit expectation gap and induces the investors' confidence simultaneously, is another theoretical contribution to the audit literature.

Third, as auditors audit the financial statements, the question arises of who audits the auditors. This study empirically supports that the role of independent audit oversight is vital to maintain the auditors' perceived independence, reduce the audit expectation gap, and induce the investors' confidence. Fourth, the practical implication regards guiding the audit professionals and audit regulators. Reforms in audit regulation are usually made to fulfil the users' expectation, and if those reforms are not based on the proper judgment of what the users actually anticipate, those reforms will be impractical. This study result provides guidance to the regulators that the existence of any audit expectation gap negatively impacts the investors' confidence; hence, this provides motivation for taking care of any expectation gap. The regulators and standard setters in the audit profession should set standards that will allow the auditors to provide more accurate statements regarding whether the entity is free form fraudulent financial reporting, continue as a going concern, and signal any financial catastrophe as well as provide a basis that environment and social reports are reliable and credible. Further, as an expectation gap is found regarding the auditors' role in assessing other information, this scenario may drive the provision of independent audit opinions on other parts of the annual report, except the financial statements. This indicates that greater initiatives are to be taken regarding the standard settings and the scope of the new branch of audits. Fifth, building a type II formative reflective model using novel methodology, the partial least-squares structural equation model (PLS-SEM), to portray the stated relations makes the study worthwhile methodologically. Although Partial least-squares (PLS) is an approach to structural equation modeling (SEM) that is extensively used in the social sciences and many business disciplines, the general acceptance and adoption of this technique in the Accounting discipline is very slow [114]. Finally, as most of the audit research focuses on the Anglo-American environment, our study's geographic focus on a developing economy perspective will bring the audit regulators and practitioners new insight regarding the role of auditors in building investors' confidence.

\subsection{Limitations and Future Research Directions}

This is the first empirical study, so far, to relate the audit expectation gap with investors' confidence; however, it is accompanied by some limitations. First, to assess the audit expectation gap, this study only considered the responses of auditors and only one type of user of financial statements (i.e., the investor). Moreover, the investor groups only included the institutional investor. Future study could involve non-professional investors and allow a comparative study on the assessment of professional and non-professional investors. Due to the difference in the level of knowledge and sophistication between these two groups, future study could depict different results. There is also a large stakeholder group surrounding the audited information that includes creditors, regulatory authorities, financial analysts, and credit analysts. Assessing the audit expectation gaps of different stakeholder groups is also necessary. Future research may include the perceptions of individual investors, creditors, and other stakeholder groups. Second, due to the difficulties in data collection procedures in the developing country, this study result represents a small sample of 174 respondents only. Future research may be conducted on a large scale to observe the audit expectation gap. Furthermore, a new slice of the audit expectation gap regarding the expectation for assurance on other information has been identified in 
this study. Future research may focus on the assurance on other information, assurance beyond the financial statements, such as corporate social and environmental reporting, as users stated those are vital for making investment decisions and ensuring sustainability of the entity.

\section{Conclusions}

This study's objective was to assess which audit expectation gap actually exists, whether those gaps have any impact on the investors' confidence, and how to mitigate those gaps to uphold the investors' confidence. This study assessed the presence of some unreasonable audit expectation gaps and also some sensible gaps. Moreover, analytical results demonstrate that the existence of an audit expectation gap adversely affects the investors' confidence. If the auditors maintain perceived independence and improve the level of communication, the audit expectation gap can be abridged, and the investors will have superior confidence in the audit. The role of independent audit oversight can also contribute in monitoring the auditors' perceived independence and ensuring greater confidence in the audit service. According to Haddrill [115] "There is a loss of confidence in audit, and I think that the industry needs to address that urgently", and this study is an endeavor to address this issue.

Supplementary Materials: The following are available online at http://www.mdpi.com/2071-1050/11/20/5798/s1. Table S1. List of Measures.

Author Contributions: T.A. wrote the first draft, collected data, performed the data analysis; T.A. and F.X. designed the study, revised and finalized the paper. F.X. administered and supervised the project.

Funding: This research was funded by the National Social Science Foundation of China under project No. 15BJY065.

Conflicts of Interest: Authors disclose no conflict of interest.

Data Accessibility Statement: The data that support the findings of this study are available from the corresponding author, upon reasonable request.

\section{References}

1. Monroe, G.S.; Woodliff, D.R. Great Expectations: Public Perceptions of the Auditor's Role. Aust. Account. Rev. 1994, 4, 42-53. [CrossRef]

2. Institute of Chartered Accountants of England \& Wales (ICAEW). Reconciling Stakeholders Expectation of Audit. Audit Quality Forum. 2008. Available online: www.icaew.co.uk/auditquality (accessed on 5 January 2019).

3. Eilifsen, A.; Messier, W.F., Jr. A Review and Integration of Archival Research. J. Account. Lit. 2000, 19, 1-43.

4. Jensen, M.C.; Meckling, W.H. Theory of the Firm: Managerial Behavior, Agency Costs and Ownership Structure. J. Financ. Econ. 1976, 3, 305-360. [CrossRef]

5. Howieson, B. Quis Auditoret Ipsos Auditores? Can Auditors Be Trusted? Aust. Account. Rev. 2013, 23, 295-306. [CrossRef]

6. Baker, C.R.; Bédard, J.; Hauret, C.P.D. The Regulation of Statutory Auditing: An Institutional Theory Approach. Manag. Audit. J. 2014, 29, 371-394. [CrossRef]

7. KPMG. The Importance of Confidence and Trust: Stakeholders Perspective. 2018. Available online: https://home.kpmg.com/xx/en/home/insights/2018/04/building-confidence-and-trust-in-capitalmarkets.html (accessed on 18 October 2018).

8. Porter, B. An Empirical Study of the Audit Expectation-Performance Gap. Account. Bus. Res. 1993, 24, 49-68. [CrossRef]

9. Porter, B.; Gowthorpe, C. Audit Expectation-Performance Gap in the United Kingdom in 1999 and Comparison with the Gap in New Zealand in 1989 and in 1999; The Institute of Chartered Accountants of Scotland: Edinburgh, UK, 2004.

10. Porter, B.; Ó Hogartaigh, C.; Baskerville, R. Audit Expectation-Performance Gap Revisited: Evidence from New Zealand and the United Kingdom. Part 1: The Gap in New Zealand and the United Kingdom in 2008. Int. J. Audit. 2012, 16, 101-129. [CrossRef]

11. Broderick, A. Role Theory and the Management of Service Encounters. Serv. Ind. J. 1999, 19, 117-131. [CrossRef] 
12. Barker, P. Audit Committees: Solution to a Crisis of Trust? Account. Irel. 2002, 34, 6.

13. Porter, B.; Simon, J.; Hatherly, D.J. Principles of External Auditing; John Wiley \& Sons: Hoboken, NJ, USA, 2008; Volume 3.

14. Financial Reporting Council (FRC). Enhancing Confidence in the Value of Audit, A Research Report Commissioned by the Financial Reporting Council. 2016. Available online: https: //www.frc.org.uk/getattachment/382e1ad9-5b7a-4297-849b1d415420fdc4/Impact-Assessment-AuditRegulation-and-Directive-September-2015.pdf (accessed on 18 September 2018).

15. Stephen, K. Auditing's Expectation Gap is Worse than ever Financial Times. The Financial Times. 14 January 2018. Available online: https://www.ft.com (accessed on 10 August 2018).

16. Sikka, P.; Puxty, A.; Willmott, H.; Cooper, C. The Impossibility of Eliminating the Expectations Gap: Some Theory and Evidence. Crit. Perspect. Account. 1998, 9, 299-330. [CrossRef]

17. Lee, T.; Ali, A.M.; Gloeck, J. The Audit Expectation Gap in Malaysia: An Investigation into its Causes and Remedies. S. Afr. J. Account. Audit. Res. 2009, 9, 57-88.

18. Humphrey, C.; Moizer, P.; Turley, S. The Audit Expectations Gap-Plus Ca Change, Plus C'est La Meme Chose? Crit. Perspect. Account. 1992, 3, 137-161. [CrossRef]

19. Salehi, M.; Azary, Z. Fraud Detection and Audit Expectation Gap: Empirical Evidence from Iranian Bankers. Int. J. Bus. Manag. 2009, 3, 65-77. [CrossRef]

20. Mock, T.J.; Bédard, J.; Coram, P.J.; Davis, S.M.; Espahbodi, R.; Warne, R.C. The Audit Reporting Model: Current Research Synthesis and Implications. Auditing 2012, 32, 323-351. [CrossRef]

21. American Institute of Certified Public Accountants (AICPA). Commission on Auditors, Responsibilities Report: Conclusions and Recommendations; AICPA: New York, NY, USA, 1978.

22. Gray, G.L.; Turner, J.L.; Coram, P.J.; Mock, T.J. Perceptions and Misperceptions Regarding the Unqualified Auditor's Report by Financial Statement Preparers, Users, and Auditors. Account. Horiz. 2011, 25, 659-684. [CrossRef]

23. Ruhnke, K.; Schmidt, M. The Audit Expectation Gap: Existence, Causes, and the Impact of Changes. Account. Bus. Res. 2014, 44, 572-601. [CrossRef]

24. Public Company Accounting Oversight Board (PCAOB). Concept Release on Auditor Independence and Audit Firm Rotation; PCAOB: Washington, DC, USA, 2011.

25. International Federation of Accountants (IFAC). Legal and Regulatory Environment; IFAC: Dhaka, Bangladesh, 2017. Available online: https://www.ifac.org/about-ifac/membership/country/bangladesh (accessed on 12 September 2018).

26. Shil, N.C. Stewardship, Transparency, Accountability, and Reporting [Star]. A Journey Enlightening. Cost Manag. 2015, 43, 5-12.

27. Porter, B. Narrowing the Audit Expectation-Performance Gap: A Contemporary Approach. Pac. Account. Rev. 1991, 3, 1-36.

28. Monroe, G.S.; Woodliff, D.R. An Empirical Investigation of the Audit Expectation Gap: Australian Evidence. Account. Financ. 1994, 34, 47-74. [CrossRef]

29. Frank, K.E.; Smith, J.K.; Lowe, D.J. The Expectation Gap: Perceptual Differences between Auditors, Jurors and Students. Manag. Audit. J. 2001, 16, 145-150. [CrossRef]

30. Elliott, W.B.; Hodge, F.D.; Kennedy, J.J.; Pronk, M.; Are, M.B.A. Students a Good Proxy for Nonprofessional Investors? Account. Rev. 2007, 82, 139-168. [CrossRef]

31. Monroe, G.S.; Woodliff, D.R. The Effect of Education on the Audit Expectation Gap. Account. Financ. 1993, 33, 61-78. [CrossRef]

32. McEnroe, J.E.; Martens, S.C. Auditors and Investors Perceptions of the "Expectation Gap". Account. Horiz. 2001, 15, 345-358. [CrossRef]

33. Wolf, F.M.; Claypool, G.A.; Tackett, J.A. Audit Disaster Futures: Antidotes for the Expectation Gap? Manag. Audit. J. 1999, 14, 468-478. [CrossRef]

34. Akther, T.; Xu, F. Stakeholders Trust Towards the Role of Auditors: A Synopsis of Audit Expectation Gap. In Proceedings of the 15th International Conference on Innovation \& Management, Yamaguchi, Japan, 27-29 November 2018.

35. Best, P.J.; Buckby, S.; Tan, C. Evidence of the Audit Expectation Gap in Singapore. Manag. Audit. J. 2001, 16, 134-144. [CrossRef] 
36. Lin, Z.J.; Chen, F. An Empirical Study of Audit 'Expectation Gap' in the People's Republic of China. Int. J. Audit. 2004, 8, 93-115. [CrossRef]

37. Dixon, R.; Woodhead, A.D.; Sohliman, M. An investigation of the expectation gap in Egypt. Manag. Audit. J. 2006, 21, 293-302. [CrossRef]

38. Siddiqui, J.; Nasreen, T.; ChoudhuryeLema, A. The Audit Expectations Gap and the Role of Audit Education: The Case of an Emerging Economy. Manag. Audit. J. 2009, 24, 564-583. [CrossRef]

39. Pourheydari, O.; Abousaiedi, M. An Empirical Investigation of the Audit Expectations Gap in Iran. J. Islamic Account. Bus. Res. 2011, 2, 63-76. [CrossRef]

40. International Auditing \& Assurance Standard Board (IAASB). ISA 240 Summary: The Auditor's Responsibilities Relating to Fraud in an Audit of Financial Statement; IAASB: New York, NY, USA, 2009.

41. Porter, B.A. The Audit Trinity: The Key to Securing Corporate Accountability. Manag. Audit. J. 2009, 24, 156-182. [CrossRef]

42. Asare, S.K.; Wright, A.M. Investors, Auditors, and Lenders Understanding of the Message Conveyed by the Standard Audit Report on the Financial Statements. Account. Horiz. 2012, 26, 193-217. [CrossRef]

43. Gold, A.; Gronewold, U.; Pott, C. The ISA 700 Auditor's Report and the Audit Expectation Gap-Do Explanations Matter? Int. J. Audit. 2012, 16, 286-307. [CrossRef]

44. Fadzly, M.N.; Ahmad, Z. Audit Expectation Gap: The Case of Malaysia. Manag. Audit. J. 2004, 19, 897-915. [CrossRef]

45. Carson, E.; Fargher, N.L.; Geiger, M.A.; Lennox, C.S.; Raghunandan, K.; Willekens, M. Audit Reporting for Going-Concern Uncertainty: A Research Synthesis. Auditing 2012, 32, 353-384. [CrossRef]

46. Financial Accounting Standard Board (FASB). Proposed Statement of Financial Accounting Standards, Going Concern; FASB: Norwalk, CT, USA, 2008.

47. Financial Accounting Standard Board (FASB). Disclosures about Risks and Uncertainties and the Liquidation Basis of Accounting; FASB: Norwalk, CT, USA, 2011.

48. International Auditing \& Assurance Standard Board (IAASB). Invitation to Comment: Improving the Auditor's Report; International Federation of Accountants: New York, NY, USA, 2012.

49. International Auditing \& Assurance Standard Board (IAASB). Going Concern, ISA 570; IAASB: New York, NY, USA, 2009.

50. International Auditing \& Assurance Standard Board (IAASB). Forming an Opinion and Reporting on Financial Statements, ISA700 Revised; IAASB: New York, NY, USA, 2015.

51. Bryan, B.J.; Smith, L.M. Faculty perspectives of auditing topics. Issues Account. Educ. 1997, 12, 1.

52. Mock, T.J.; Strohm, C.; Swartz, K.M. An examination of worldwide assured sustainability reporting. Aust. Account. Rev. 2007, 17, 67-77. [CrossRef]

53. Simnett, R.; Vanstraelen, A.; Chua, W.F. Assurance on sustainability reports: An international comparison. Account. Rev. 2009, 84, 937-967. [CrossRef]

54. Brown-Liburd, H.; Zamora, V.L. The role of corporate social responsibility (CSR) assurance in investors' judgments when managerial pay is explicitly tied to CSR performance. Auditing 2014, 34, 75-96. [CrossRef]

55. Cohen, J.R.; Gaynor, L.M.; Krishnamoorthy, G.; Wright, A.M. The impact on auditor judgments of CEO influence on audit committee independence. Auditing 2011, 30, 129-147. [CrossRef]

56. Nelson, M.W. Ameliorating Conflicts of Interest in Auditing: Effects of Recent Reforms on Auditors and their Clients. Acad. Manag. Rev. 2006, 31, 30-42. [CrossRef]

57. European Commission. Green Paper Audit Policy: Lessons from the Crisis. 2010. Available online: https://eur-lex.europa.eu/legal-content/EN/TXT/?uri=CELEX:52010DC0561 (accessed on 22 December 2018).

58. Bazerman, M.H.; Moore, D. Is it Time for Auditor Independence Yet? Account. Organ. Soc. 2011, 36, 310-312. [CrossRef]

59. Jamal, K.; Sunder, S. Is Mandated Independence Necessary for Audit Quality? Account. Organ. Soc. 2011, 36, 284-292. [CrossRef]

60. Beattie, V.; Brandt, R.; Fearnley, S. Perceptions of Auditor Independence: U.K. Evidence. J. Int. Account. Audit. Tax. 1999, 8, 67-107. [CrossRef]

61. DeFond, M.L.; Raghunandan, K.; Subramanyam, K.R. Do Non-Audit Service Fees Impair Auditor Independence? Evidence from Going Concern Audit Opinions. J. Account. Res. 2002, 40, 1247-1274. [CrossRef] 
62. Ashbaugh, H.; LaFond, R.; Mayhew, B.W. Do Nonaudit Services Compromise Auditor Independence? Further Evidence. Account. Rev. 2003, 78, 611-639. [CrossRef]

63. Lim, C.-Y.; Tan, H.-T. Non-Audit Service Fees and Audit Quality: The Impact of Auditor Specialization. J. Account. Res. 2008, 46, 199-246. [CrossRef]

64. Hendrickson, H. Relevant Financial Reporting Questions Not Asked by the Accounting Profession. Crit. Perspect. Account. 1998, 9, 489-505. [CrossRef]

65. Umar, A.; Anandarajan, A. Dimensions of Pressures Faced by Auditors and its Impact on Auditors' Independence: A Comparative Study of the USA and Australia. Manag. Audit. J. 2004, 19, 99-116. [CrossRef]

66. Kinney, W.R., Jr.; Palmrose, Z.V.; Scholz, S. Auditor independence, non-audit services, and restatements: Was the US government right? J. Account. Res. 2004, 42, 561-588. [CrossRef]

67. Salehi, M.; Rostami, V. Audit expectation gap: international evidences. Int. J. Acad. Res. 2009, 1, 140-146.

68. Mo Koo, C.; Seog Sim, H. On the role conflict of auditors in Korea. Accounting. Audit. Account. J. 1999, 12, 206-219. [CrossRef]

69. Yip, P.C.-W.; Pang, E. Investors Perceptions of Auditor Independence: Evidence from Hong Kong. e-J. Soc. Behav. Res. Bus. 2017, 8, 70-82.

70. Bazerman, M.H.; Morgan, K.P.; Loewenstein, G.F. The Impossibility of Auditor Independence. Sloan Manag. Rev. 1997, 38, 89-94.

71. Salleh, Z.; Stewart, J. The Role of the Audit Committee in resolving auditor-client disagreements: A Malaysian study. Account. Audit. Account. J. 2012, 25, 1340-1372. [CrossRef]

72. Krishnamoorthy, G.; Wright, A.; Cohen, J. Audit Committee Effectiveness and Financial Reporting Quality: Implications for Auditor Independence. Aust. Account. Rev. 2002, 12, 3-13. [CrossRef]

73. Coram, P.J.; Mock, T.J.; Turner, J.L.; Gray, G.L. The Communicative Value of the Auditor's Report. Aust. Account. Rev. 2011, 21, 235-252. [CrossRef]

74. Haddrill, S. Speech by Stephen Haddrill, Chief Executive of the U.K. Financial Reporting Council, to the European Commission Conference on Financial Reporting and Auditing on Thursday 10th February 2011. Available online: https:/www.frc.org.uk/news/july-2018/speech-by-stephen-haddrill-corporate-governance (accessed on 10 August 2018).

75. Public Company Accounting Oversight Board (PCAOB). Concept Release on Possible Revisions to PCAOB Standards Related to Reports on Audited Financial Statements and Related Amendments to PCAOB Standards; PCAOB: Washington, DC, USA, 2011.

76. International Auditing \& Assurance Standard Board (IAASB). The New Auditor's Report: Greater Transparency into the Financial Statement Audit. 2015. Available online: www.iaasb.org/auditor-reporting (accessed on 10 January 2019).

77. International Auditing \& Assurance Standard Board (IAASB). The Auditor's Responsibilities Relating to Other Information in Documents Containing Audited Financial Statements; ISA 701; IAASB: New York, NY, USA, 2015.

78. Epstein, M.J.; Geiger, M.A. Investor Views of Audit Assurance: Recent Evidence of the Expectation Gap. J. Account. 1994, 177, 60.

79. Kim, R.; Kim, S.; Musa, P.M. When does comparability better enhance relevance? Policy implications from empirical evidence. J. Account. Public Policy 2018, 37, 436-457. [CrossRef]

80. Nair, R.; Rittenberg, L. Messages perceived from audit, review, and compilation reports: Extension to more diverse groups. Auditing 1987, 7, 15-38.

81. Schelluch, P.; Green, W. The Expectation Gap: The Next Step. Aust. Account. Rev. 1996, 6, 19-23. [CrossRef]

82. Hogan, C.E.; Rezaee, Z.; Riley, R.A.; Velury, U.K. Financial Statement Fraud: Insights from the Academic Literature. Auditing 2008, 27, 231-252. [CrossRef]

83. Bertin, E.; Jaussaud, J. Regulation of statutory audit in China. Asian Bus. Manag. 2003, 2, 267-280. [CrossRef]

84. Humphrey, C.; Moizer, P.; Turley, S. The Audit Expectations Gap in Britain: An Empirical Investigation. Account. Bus. Res. 1993, 23, 395-411. [CrossRef]

85. Olagunju, A. An Empirical Analysis of the Impact of Auditors Independence on the Credibility of the Financial Statement in Nigeria. Res. J. Financ. Account. 2011, 2, 82-99.

86. Baotham, S.; Ussahawanitchakit, P. Audit Independence, Quality, and Credibility: Effects on Reputation and Sustainable Success of CPAs in Thailand. Int. J. Bus. Res. 2009, 9, 1-25.

87. Okafor, C.A.; Otalor, J.I. Narrowing the expectation gap in auditing: the role of the auditing profession. Res. J. Financ. Account. 2013, 4, 43-52. 
88. DiMaggio, P.J. Constructing an organizational field as a professional project: US art museums, 1920-1940. In The New Institutionalism in Organizational Analysis; Powell, W.W., DiMaggio, P.J., Eds.; University of Chicago Press: Chicago, IL, USA, 1991; pp. 267-293.

89. Hossen, M.S. Financial Reporting Act (FRA), 2015: A Revolutionary Era for Ensuring Effective Capital Market and Economic Development in Bangladesh. Glob. J. Manag. Bus. Res. 2016, 16, 13-20.

90. Ahmed, M. Role and Responsibilities of Professional Accountants. Speech in Seminar on Financial Reporting Act, ICMAB News. Cost Manag. 2017, 45, 54.

91. Schelluch, P.; Gay, G. Assurance Provided by Auditors' Reports on Prospective Financial Information: Implications for the Expectation Gap. Account. Financ. 2006, 46, 653-676. [CrossRef]

92. Burns, A.C.; Bush, R.F. Marketing Research: Online Research Applications; Prentice Hall: Upper Saddle River, NJ, USA, 2003.

93. Karkacier, A.; Ertaş, F.C. Independent auditing effect on investment decisions of institutional investors. Account. Manag. Inf. Syst. 2017, 16, 297-319. [CrossRef]

94. Akın, F.; Ve Ece, N. Kurumsal yatırımcılar ve Türk sermaye piyasasında kurumsal yatırımcıların gelişimi üzerine bir değerlendirme (Institutional investors and an evaluation on the development of institutional investors in the Turkish capital market). Abmyo Derg. 2011, 22, 11-26.

95. IBM Corp. Released 2016. IBM SPSS Statistics for Windows, Version 24.0. Armonk; IBM Corp: New York, NY, USA, 2016.

96. Tavakol, M.; Dennick, R. Making Sense of Cronbach's Alpha. Int. J. Med. Educ. 2011, 2, 53-55. [CrossRef] [PubMed]

97. Jarque, C.; Bera, A. Efficient tests for normality, homoscedasticity and serial independence of regression residuals. Econ. Lett. 1980, 6, 255-259. [CrossRef]

98. Hair, J.F.; Ringle, C.M.; Sarstedt, M. PLS-SEM: Indeed a Silver Bullet. J. Mark. Theory Pract. 2011, 19, $139-152$. [CrossRef]

99. Ringle, C.M.; Wende, S.; Becker, J.-M. SmartPLS 3. 2015. Available online: http://www.smartpls.com (accessed on 24 January 2019).

100. Diamantopoulos, A.; Siguaw, J.A. Introducing LISREL; Sage: Thousand Oaks, CA, USA, 2000.

101. Becker, J.-M.; Klein, K.; Wetzels, M. Hierarchical Latent Variable Models in PLS-SEM: Guidelines for Using Reflective-Formative Type Models. Long Range Plan. 2012, 45, 359-394. [CrossRef]

102. Van Riel, A.; Henseler, J.; Kemény, I.; Sasovova, Z. Estimating Hierarchical Constructs Using Consistent Partial Least Squares: The Case of Second-Order Composites of Common Factors. Ind. Manag. Data Syst. 2017, 117, 459-477. [CrossRef]

103. Edwards, J.R.; Bagozzi, R.P. On the Nature and Direction of Relationships between Constructs and Measures. Psychol. Methods 2000, 5, 155-174. [CrossRef]

104. Petter, S.; Straub, D.; Rai, A. Specifying Formative Constructs in Information Systems Research. MIS Q. 2007, 31, 623-656. [CrossRef]

105. Dijkstra, T.K. Latent Variables and Indices: Herman Wold's Basic Design and Partial Least Squares. In Handbook of Partial Least Squares: Concepts, Methods and Applications; Springer: Heidelberg, Germany, 2010; pp. 23-46.

106. Dijkstra, T.K.; Schermelleh-Engel, K. Consistent Partial Least Squares for Nonlinear Structural Equation Models. Psychometrika 2014, 79, 585-604. [CrossRef]

107. Dijkstra, T.K.; Henseler, J. Consistent Partial Least Squares Path Modeling. MIS Q. 2015, 39, $297-316$. [CrossRef]

108. Hair, J.F.; Sarstedt, M.; Ringle, C.M.; Mena, J.A. An Assessment of the Use of Partial Least Squares Structural Equation Modeling in Marketing Research. J. Acad. Mark. Sci. 2012, 40, 414-433113. [CrossRef]

109. Diamantopoulos, A.; Siguaw, J.A. Formative Versus Reflective Indicators in Organizational Measure Development: A Comparison and Empirical Illustration. Br. J. Manag. 2006, 17, 263-282. [CrossRef]

110. Hair, J.F.; Anderson, R.E.; Tatham, R.L.; Black, W.C. Multivariate Data Analyses with Readings; Prentice Hall: Englewood Cliffs, NJ, USA, 1995.

111. Allini, A.; Aria, M.; Macchioni, R.; Zagaria, C. Motivations behind users' participation in the standard-setting process: Focus on financial analysts. J. Account. Public Policy 2018, 37, 207-225. [CrossRef] 
112. International Auditing \& Assurance Standard Board (IAASB). A Framework for Audit Quality. 2014. Available online: https://www.ifac.org/auditing-assurance/focus-audit-quality (accessed on 4 September 2018).

113. Hanson, J.D. PCAOB Update-Recent Activities and Next Steps. In Proceedings of the 2016 SEC and Financial Reporting Institute Conference, Los Angeles, CA, USA, 9 June 2016.

114. Lee, L.; Petter, S.; Fayard, D.; Robinson, S. On the Use of Partial Least Squares Path Modeling in Accounting Research. Int. J. Account. Inf. Syst. 2011, 12, 305-328. [CrossRef]

115. Haddrill, S. FRC's Annual Development Audit. 2018. Available online: https://www.frc.org.uk/ getattachment/f211c972-73ab-4bf2-b696-820eadc538bf/SH-Developments-in-Audit-FINAL-v2.pdf (accessed on 10 December 2018).

(C) 2019 by the authors. Licensee MDPI, Basel, Switzerland. This article is an open access article distributed under the terms and conditions of the Creative Commons Attribution (CC BY) license (http://creativecommons.org/licenses/by/4.0/). 